\title{
THE IMPLICATION OF AIRLINES DEREGULATION IN THE END OF THE 2OTH CENTURY ON INDUSTRIAL DEVELOPMENT OF COMMERCIAL AIR TRANSPORT SCHEDULE IN INDONESIA
}

\author{
Tiarto $^{1}$ \\ 1. Sekolah Tinggi Penerbangan Indonesia \\ corresponding author: tiartomustadja@rocketmail.com.
}

\begin{abstract}
Airlines deregulation is intended to remove state-sponsored protectionism, leading to economic liberalization so that entry conditions are easy and cheap, but the results were mostly disappointing. The research used a method of Structure, Conduct and Performance (SCP method). The results of this study indicate that the market structure of oligopoly is better than before deregulation. Conduct, there is price competition so tariff becomes cheaper. The performance of airlines is also getting better as shown by the increasing of production efficiency. Significant reversal of market share before and after deregulation of comparison between SOEs and POEs from $75.40 \%: 24.60 \%$ to $34.75 \%$ : $65.25 \%$. Economic regulation by the government dilemma in addition to causing differences of views between the interests of producers and the interests of consumers, also the industry becomes more concentrated on the main players, and serves as a tool pricing and prevent entry of new competitors. Tribulation increased : increased number of flight delays, skyrocketing prices during busy times, the difficulty of getting tickets happens at the last minute and so forth, fewer airlines and routes, airport density.
\end{abstract}

Keywords: Commerce Air Transport, Competition, Airlines Deregulation.

\section{Introduction}

Driven by a desire to promote a less regulated economic environment and lower prices for commercial air transport services, airlines deregulation in Indonesia in the late 20th century was introduced. Airlines Deregulation in line with the birth of Law Number 5 Year 1999 on Prohibition of Monopolistic Practices and Unfair Business Competition. As previously done in the United States in 1978 and in the EU in 1987, the airlines deregulation in Indonesia is a government economic regulation with the primary aim of reducing price competition and barriers to entry of new competitors. The latest meaning of deregulation is more meaningful as (Amadeo 2015): Deregulation is when the government reduces or eliminate industry restrictions to improve the ease of doing business. The government removes a regulation when businesses complain it interferes too much with their ability to compete, especially with foreign companies. However, consumer group 
also prompt deregulation by pointing out how industry leaders are too cozy with their regulatory authorities (Kimberly. Amadeo: 2016).

Airlines Deregulation in Indonesia begins with: (1) issuance of Presidential Decree No. 33/2000 on the Revocation of Presidential Instruction No. 1 of 1980 on the Prohibition of Aircraft Operation Permit, and Permit which is intended to facilitate the mechanism and procedures for the procurement of aircraft from outside (2) Decree of the Minister of Transportation Number 11 Year 2001 on the operation of air transport, which makes it easy for anyone who wants to establish a scheduled airline as long as it meets the requirements, has enough control over 2 (two) aircraft. The changes are hug, if before the deregulation there were only 5 (five) scheduled airlines, while after deregulation increased rapidly to 73 companies. Similarly, passanger carried has increased tenfold from about 9 million to 90 million.

Many circles argue that consequences of deregulation have been very adverse. Garuda Airlines, which is the leader in the domestic aviation market, are now laggards in every category, including fleet age, service quality, fewer and fewer flights are on time. Airport congestion has become a staple of late-night comedy shows. An even higher percentage of bags are lost or misplaced. Last-minute seats are harder to find. Passenger complaints have skyrocketed,.airlines service by any standard, has become unacceptable.

The result of the study (Amadeo 2015) in the Journal of Transportation and Logistics Management (JMTRANLOG) STMT Trisakti, concluded that airlines deregulation led to the emergence of LCC. It was concluded that domestic passenger tendency as much as $78 \%$ was choosing LCC.

The purpose and objective of each regulation is basically in order for a better development. However, to assess whether the results are better or worse, there is a need for performance measurement in the implementation of air transport. (Martin 1999) describes the power of performance measurement : 
If you do not measure results, you can not tell the difference between success and failure. If you can not see your success you can not appreciate it.

\section{Method}

This research used (Structure-Conduct-Performance method paradigm). This method formulates that a perfect competitive market will result in a maximum allocation of resources, while monopoly will lead to inefficiency (Martin 1999). The one-way causal relationship between structure, conduct and performance as shown in chart 1 follows:

Chart 1.

Relationship Structure, Conduct and Performance

\section{STRUCTURE}

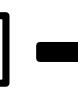

PERFORMANCE

This approach formulates that the variables of the industrial structure will affect the conduct, then the conduct affects the performance of the industry, then if the company in the industry more, the market will be more competitive and generate optimal allocation of resources so that the industry performance will be better. Whereas a small number of companies in the industry will make the market become concentrated and business actors in the industry will tend to behave in a monopoly that makes resource allocation unoptimal and leads to inefficiency in the industry.

The framework of industrial economic analysis with Structure-ConductPerformance method is the simplest version. At the bottom of this view are:

1. The market structure determines the conduct of companies in the market.

2. The conduct of the firm determines aspects of the performance.

Where studies from a number of these industrial economies expand the relationships that describe Structure-Conduct-Performance.

The strength of companies in the industry is measured by calculating the concentration ratio. The concentration ratio calculates how many percent of the 
output in the oligopoly market is dominated by dominant firms (four to eight firms (Pratama and Manurung (2004).) To test whether the national airline is competitive or not can be seen in the concentration ratio. But the concentration ratio tells only about the share of some of the largest airlines. In the concentration ratios it does not seem related to the amount of information about the relative size of smaller company firms in the market and provides only a limited picture of the size of the company's distribution in the market. For that reason, measuring the concentration of sales of Herfindahl Hierchman Index (HHI) This index is a combination of information on the market shares of all companies in the market/industry, not just four companies or the eight largest companies. Index (HHI) calculated by squaring the percentage of the market share of each company and then summing it up. For example, if an industry consists of 100 companies of the same size, the Herfindahl Index is $=100 \times(1)^{2}$. If the industry is a pure monopoly, the index is $10,000\left(=(100)^{2}\right.$, which is the largest index. The more number of companies in the industry and the more similar the size of these companies the HHI index is getting smaller. The index gives greater weight for companies with a larger market share (William A. McEachern, 2000).

\section{Results and Discussion}

\section{Results.}

According to the analysis of the structure, conduct and performance, the implications or effects of airlines deregulation on the development of the commercial air transport services industry in Indonesia can be explained as follows:

1. Prior to the deregulation of the number of scheduled airlines there were only five. whereas after deregulation became 73 registered companies. This means that the oligopoly market structure becomes better than before deregulation. Passenger is transported $74 \%$ by state-owned companies /SOEs, while the remaining $26 \%$ is by privately owned enterprises/POEs.

2. Period (2001-2016) measured by the number of passengers transported, has grown 10-fold more than before deregulation. If in 2001 only 9 million/year, 
the year 2016 increased close to 90 million/year.

3. Period 2001-2007, market structure shows expansion period, with peak of growth occurring in 2007. Number of airlines increased rapidly (registered) the world's highest growth area in the opinion of ICAO). Based on CR4, CR8 and HHI measurements and the number of competing firms show a very significant development. This period of market structure is better, more diffuse and competitive. Especially when compared with before deregulation.

4. Period 2008-2016. Although the number of passengers transported also continues to increase, but if measured on the number of companies that are able to compete began to show a decline. As a result the market becomes concentrated on the dominant firm holding the largest market share of business group Lion Air (+50\%), the impact of decreasing competition.

Table 1.

Market Concentration

Production of Domestic Scheduled Domestic Air Transport Period 2000-2016

Category: Number of Passengers Carried

\begin{tabular}{|c|c|c|c|c|c|c|c|}
\hline No & Year & $\begin{array}{c}\text { Numbers of } \\
\text { Companies } \\
\text { operations }\end{array}$ & Pax Carried & $\begin{array}{c}\text { CR4 } \\
(\%)\end{array}$ & $\begin{array}{c}\text { CR8 } \\
(\%)\end{array}$ & HHI & $N^{*}$ \\
\hline 1 & 2 & 3 & 4 & 5 & 6 & 7 & 8 \\
\hline 1 & 2001 & 13 & 9.168 .059 & 91 & 98 & 0,31 & 3,19 \\
\hline 2 & 2002 & 14 & 12.333 .035 & 79 & 96 & 0,21 & 4,65 \\
\hline 3 & 2003 & 14 & 19.181 .294 & 72 & 94 & 0,22 & 4,47 \\
\hline 4 & 2004 & 15 & 23.763 .950 & 67 & 90 & 0,15 & 6,75 \\
\hline 5 & 2005 & 13 & 28.813 .515 & 59 & 87 & 0,13 & 7,76 \\
\hline 6 & 2006 & 14 & 34.015 .981 & 66 & 86 & 0,13 & 7,49 \\
\hline 7 & 2007 & 14 & 36.469 .337 & 58.21 & 79.93 & 0.1298 & 7.70 \\
\hline & & & & & & & \\
\hline 8 & 2008 & 14 & 37.350 .688 & 69.30 & 95.37 & 0.1464 & 6.83 \\
\hline 9 & 2009 & 13 & 43.808 .033 & 76.12 & 95.46 & 0.1763 & 5,67 \\
\hline 10. & 2010 & 15 & 51.775 .656 & 83.98 & 96.74 & 0.2224 & 4.50 \\
\hline 11. & 2011 & 15 & 60.197 .306 & 87.72 & 98.05 & 0.2546 & 3.93 \\
\hline 12. & 2012 & 20 & 71.421 .464 & 83.75 & 95.98 & 0.2395 & 4.17 \\
\hline 13. & 2013 & 19 & 75.770 .222 & 88,04 & 95,89 & 0.2554 & 3,91 \\
\hline 14 & 2014 & 18 & 76.498 .400 & 84,72 & 97,00 & 0.2476 & 4,04 \\
\hline 15 & 2015 & 15 & 76.628 .867 & 82,18 & 96,48 & 0,2177 & 4,59 \\
\hline 16 & 2016 & 14 & 89.273 .701 & 78,80 & 96,78 & 0,2049 & 4,88 \\
\hline
\end{tabular}

Source : Tiarto : (2007 dan 2016, data processed).

$\left.\mathrm{N}^{*}\right)=$ number of equal seller).

According to a comparative analysis of the market share (table 2), before the airlines deregulation (1999) the share of SOEs airlines to POEs averaged 74\%: $26 \%$. The first 7-year period of airlines deregulation (2000-2007) has shown a 
contradictory development, SOE's share incumbent airlines declined to $24.60 \%$, while POEs airlines increased to $75.40 \%$. Similarly, after deregulation period (2007-2016) the comparison between SOEs and POEs airlines for 2016 became $34.75 \%: 65.25 \%$. So due to the airlines deregulation, the domestic aviation market share has reversed from what was originally controlled by state-owned airlines PT. GIA became by Lion (POEs airlines). Lion is now nearing the dominant position as referred to in Article 25 paragraph 2a of Law Number 5 Year 1999 concerning Prohibition of Monopolistic Practices and Unfair Business Competition, which states that "Businessman have dominant position if one group control $50 \%$ or more market share of a particular type of goods or service. Many airlines are out of business and the industry becomes concentrated on the dominant players so the number of airlines becomes less.

Table 2

Comparison of Market Share Between State-Owned Enterprises (SOEs) and Private-Owned Enterprise (POEs)

Period : 1999 - 2016

\begin{tabular}{|c|c|c|c|c|c|c|c|c|c|c|c|}
\hline \multirow{3}{*}{ No. } & \multirow{3}{*}{ year } & \multicolumn{9}{|c|}{ Share ( \% ) } & \multirow{3}{*}{$\begin{array}{c}\text { Pax } \\
\text { Carried }\end{array}$} \\
\hline & & \multicolumn{3}{|c|}{ Incumbent/SOEs(\%) } & \multicolumn{6}{|c|}{ Entrance/POEs (\%) } & \\
\hline & & GIA & $\mathrm{CL}$ & MNA & $\mathrm{BO}$ & LI & $\mathrm{BV}$ & SR & WA & Lain2 & \\
\hline \multicolumn{2}{|c|}{ Airlines: } & 1 & 2 & 3 & 4 & 5 & 6 & 7 & 8 & 9 & \\
\hline 1 & 1999 & 52 & & 23 & 13 & 1 & & & & 11 & 6.385 .481 \\
\hline \multirow[t]{2}{*}{2} & 2000 & 51 & & 23 & 14 & 1 & & & & 11 & 7.509 .831 \\
\hline & 2000 & \multicolumn{3}{|c|}{74} & \multicolumn{6}{|c|}{26} & \\
\hline 3 & 2001 & 49 & & 22 & 6 & 2 & & & & 21 & 8.986 .802 \\
\hline 4 & 2002 & 38 & & 19 & 9 & 7 & & & & 27 & 12.304 .506 \\
\hline 5 & 2003 & 29 & & 16 & 7 & 16 & & & & 32 & 19.181 .294 \\
\hline 6 & 2004 & 28 & & 11 & 3 & 21 & & & - & 37 & 23.763 .950 \\
\hline 7 & 2005 & 24 & & 8 & & 19 & 6.85 & 8,14 & 6.19 & 36,82 & 28.813 .515 \\
\hline 8 & 2006 & 20 & & 5 & & 20 & 4.94 & 9,23 & 5.94 & 34,89 & 34.015 .981 \\
\hline \multirow[t]{2}{*}{9} & 2007 & 18.82 & - & 6.78 & & 21,64 & 4.42 & 9.13 & 6.01 & 34,20 & 39.162 .332 \\
\hline & 2007 & \multicolumn{3}{|c|}{24,60} & \multicolumn{6}{|c|}{75,40} & \\
\hline 10 & 2008 & 20,49 & - & 6.62 & $\mathrm{BA}$ & 24,63 & 9.22 & 11.42 & 6.21 & 21,41 & 37.405 .437 \\
\hline 11 & 2009 & 19.17 & - & 5.01 & & 30,54 & 8.11 & 13.55 & 2.90 & 20,72 & 43.808 .033 \\
\hline 12 & 2010 & 19.30 & - & 4.56 & & 38,05 & 4.54 & 13,55 & 1,61 & 18,39 & 51.775 .656 \\
\hline 13 & 2011 & 22,81 & - & 3.64 & & 41,48 & 11.24 & 12.26 & 3.32 & 5,12 & 60.197 .306 \\
\hline 14 & 2012 & 21.07 & 2,02 & 3.53 & & 41,22 & 9.60 & 11.34 & 3.64 & 6,78 & 71.421 .464 \\
\hline 15 & 2013 & 22.08 & 7.05 & 1,79 & 1 & 43,04 & - & 11,36 & 4.51 & 9,15 & 75.770 .222 \\
\hline 16 & 2014 & 23,91 & 9,87 & - & 2,5 & 40,69 & - & 10,25 & 4,48 & 8,34 & 76.498 .400 \\
\hline 17 & 2015 & 26,05 & 12,24 & - & 6,0 & 34,57 & & 9,32 & 4,48 & 7,34 & 76.628 .867 \\
\hline \multirow[t]{2}{*}{18} & 2016 & 22,37 & 12,38 & - & 8,2 & 34,64 & & 9,41 & 5,49 & 6,43 & 89.273 .701 \\
\hline & 2016 & \multicolumn{3}{|c|}{$\mathrm{BUMN}=34,75 \%$} & \multicolumn{6}{|c|}{$\begin{array}{l}\text { BUMS = Lion group }(1 \mathrm{l}+\mathrm{wa}+\mathrm{ba}) \\
=48,4 \% 1+\text { Lain } 2=16,84 \%)=65,25 \%\end{array}$} & \\
\hline
\end{tabular}


Explanation:

$1=$ GIA, $2=$ Citylink, $3=$ MNA, $4=$ Bouraq, $5=$ Lion, $6=$ Batavia, $6=$ Sriwijaya, $8=$ Wing Abadi, $9=$ Other Airlines, and $\mathrm{BA}=($ Batik Air) is a subsidiary of Lion operating in 2013. Bouraq Indonesia since 2005 and Batavia Air since January 2013 is not operating.

Source: (Tiarto, 2007 and Tiarto, 2017, data is processed)

\section{Discussion}

\section{Impact on structure}

Based on KM.127/1990 the requirement to become a scheduled commercial air transport company must be experienced for at least 5(five) years as an unscheduled airline air transport service company. As a result, the number of airlines that can compete relatively still there are only 5 (five) companies. KM.127 / 1990 on the implementation of air transport has impacted barriers to entry of new entrants and barrier to price competition. After deregulation with KM.11 / 2001, the requirement of establishing a company is very easy to simply operate 2 (two) fleets. Since it is easy for many new airlines to emerge, from 5 (five) to 73 companies (registered). Competition among airlines increased sharply, but skyrocketing prices during busy time. The diffculty of getting tickets happens at the last minute and so forth. Each airline is competing to be the best. The race to be the best is an intuitive but self-defeating competition approach. So many airlines are out of business. Impact of the economy of scale many airlines can not compete. Hence with KM.84 / 2008 the terms are added from 2 to 5 fleets, and then with Flight Act No. 1/2009 added to 10 fleets.

The provision of a minimum of 10 aircraft operated demands high capital and operational costs. Many airlines can not fulfill the requirements of a scheduled commercial air transport service company and consequently are forced to switch as an unscheduled airline air transport service company. They become a dilemma/difficulty in running their business, can be likened to have fallen on the stairs too. In fact, although through the Aviation Act No. 1 of 2009 has been given a chance for 3 years to adjust, but some airlines until now still can not meet the requirements as the provisions.

Because many airlines are out of business and the industry becomes concentrated on the dominant players so the number of airlines becomes less. 
Thus the airlines deregulation not only has a positive impact but also has more negative impacts. Positive impacts as mentioned earlier, namely the decline in price competition barriers so that tariffs become cheaper and varied. Although the above statement illustrates the implications of airlines deregulation in the United States, it is essentially almost the same as it is in Europe, much worse for Indonesia. Due to deregulation, flight delays and cancellations become miserable news every day and have a negative impact on others.

\section{Impact on Conduct}

\section{a. Collusion Fellow members of INACA Become Prohibited}

Collusion is the inter-firm agreement in the industry to divide up the market and set prices. The cartel is a group of companies that agree to collude so they can act as a single monopolist and earn a monopoly profit (W. McEachern: 2000). Collusion and Cartel in Indonesia are illegal or prohibited under Law No. 5 of 1999 on Prohibition of Monopolistic Practices and Unfair Business Competition. But first before the airlines deregulation was legalized, even the government pushed it, as did the INACA (Indonesian National Air Carrier Association). Before deregulation of collusion practices was encouraged by the government with a view to avoiding unhealthy competition among scheduled national airlines. The government facilitated the meeting of all national airlines of INACA members to convene and appealed against unfair competition. The tariff system that was mapped by the government at that time also supported. The tariff system uses a single tariff system. The meaning is only justified to use tariffs that have been set by the government, beyond that is considered to be in violation.

If INACA was previously authorized by the government (DH, Minister of Transportation) to fix the tariff of all members of the scheduled commercial airline trading association in Indonesia. Now the authority has been revoked, because it violates the laws and regulations. The 
existence of INACA in pricing is considered to be no longer needed, so some parties are advised to be dissolved. But by the government the role of INACA is still needed as a partner in representing the interests of national air transport service providers.

\section{b. More Varied Tariffs.}

Tariff structure and class become more varied, because each airline allocates seat (in percentage) different sub class. The implementation of the sub class depends on the peak season, so that the ticket price imposed by the airlines is strongly influenced by the balance between demand and supply. This condition indicates that the ticket price is created through market mechanism. Implementation of the sub class in addition to peak period, should also at the level of service provided. In view of Article 97 of the Aviation Law No. 1 of 2009, scheduled commercial air transport services are 3 (three), namely: (1) services with maximum standards (full service); (2) service with medium standard; or (3) service with minimum standards (no frill).

\section{c. The Dilemma of Economic Regulation by the Government}

Economic regulation in aviation seems to be a dilemma, judged to be criminalized, especially based on public /consumer judgments. The government is required to be fair, but any economic regulation of tariffs by the government seems to continue to cause problems seen from the point of view of the interests of producers and the interests of consumers who always contradict opinions between the two.

When the government sets tariffs, businesses and communities protest that the government should not interfere in business. When the government fixes only the upper limit, consumers protest on the grounds that the government is more in favor of the airlines / producers. Then when the government intends to balance in addition to setting the upper limit rate as well as lower border rates are protested by a third party in 
this case KPPU (Commission of Business Competition Supervisor). KPPU reasoned that the determination of the lower tariff by the government will shut down the competition that is running. When the government returns only set the upper limit rate, also re-protested by consumers with more reason to side with the interests of airlines / producers. As stated (Mc Earhern: 2000): there are 2 (two) views on economic regulation by the government. The first view of regulation is for the benefit of society by controlling the price/tariff that is for the most efficient market if only served by one or a few companies. The second view of economic regulation is not primarily for the benefit of society/ consumers, but the special interests of the producers. This is exactly the same as INACA.

Besides, economic regulation on aviation industry in Indonesia causes industry to become concentrated dominant firm Lion and Garuda, serves as a price controling tool and prevents new competitor from coming in.

\section{Impacts on Performance}

After the airlines deregulation more and more new airlines emerged because of the ease in setting up the airline. The increasing number of airlines makes the industry more competitive and can provide a rational price so that consumers have more options for aviation services as needed. Since airlines deregulation has encouraged the emergence of low cost carriers/LCC. Airlines deregulation also affects production efficiency in the national aviation industry. This can be seen in the increased Passenger Load Factor (P/F).

Basically, airlines deregulation that addresses the issues of air transport, tariff setting, market entry, competition policy can be said to be sufficient and respond to the needs of society, thus creating a conducive climate for the aviation industry itself.

The high demand for capital and operational costs in the aviation industry requires careful management of players. They are required to choose two 
common options that apply today, whether to focus on creating core values of service or focusing on price competition. Garuda chose to focus as airlines offering full service to its passengers, while many others focus on competitive pricing strategies.

Airlines deregulation that has been in operation since the 2000s up to now has had implications for the result of fewer airlines and fewer routes due to the change of the hub and spoke system to the point to point, the more varied tariffs when compared to the before deregulation.

\section{Conclusion}

From the results of the analysis with the Structure-Behavior-Performance method on the economic development of the scheduled commercial air transport services industry in Indonesia, the airlines deregulation has practical implications as follows :

1) The oligopoly market structure is better than before the flight deregulation. in Indonesia.

2) At the beginning of deregulation the entry conditions became very easy, many new airlines sprung from 5 to 73 airlines, but gradually became more difficult than at the beginning of deregulation.

3) Collusion between fellow airlines incorporated in INACA members is prohibited.

4) Economic regulation in aviation has become a dilemma, both by producers and consumers, the government is required to be fair.

5) Racing to be the best is an intuitive but self-defeating competition approach. As a result many new airlines are falling.

6) Result of airlines deregulation has implications for a smaller number of airlines, fewer routes and more tariff variations.

\section{References}

Amadeo, Kimberly, 2016, Why Airlines Travel is So Miserable, and Other Effect 
of Deregulation, Deregulation : Definition, Pros, Cons, Example.

Bailey, E.F., (1992), Airlines Deregulation Confronting the Paradoxes, Regulation : The Cato Review of Business and Government 15, No. 3. (http://www.cato.org/pubs/regulation/regv15n3/reg15n3-bailey. Html)

Direktorat Angkutan Udara, Direktorat Jenderal Perhubungan Udara, Departemen Perhubungan, Statistik Angkutan Udara Tentang Data Angkutan Udara Dalam Negeri dan Luar Negeri tahun 2001 s/d 2016.

Bailey, E.E., (1992), Airlines Deregulation Confronting the Paradoxes, Regulation; The Cato Review of Business and Government 15, No. 3 (6) www.cato.org/pubs/regulation/reg15n3/reg15n3-bailey.html.

Martin, Stephen, 1994. Industrial Economics : Economic Analysis and Public Policy. Second Edition, Prentice-Hall, Inc.

William A. McEachern,2000. Economics : A Contemporary Introduction, @ 2000 by South-Western College Publishing, a division of Thomson Learning.

David Osborne and Ted Gaebler, Reinventing Government : How The Entepreneurial Spirit is Transforming the Public Sector, Copyright @ 1992

David Osborne and Peter Plastrik, Banishing Bereaucracy : The Strategic for Reinventing Government, Copyright@ 1997.

Kokoh Ronald Aruan, 2015, Kepala Divisi Konsultasi PPM Managemen, Menebak arah low cost carrier. KRA@ppm-managemen.ac.id.

Steven Morrison and Clifford Winston, 1986. The Economics Effect of Airlines Deregulation. Studies in the Regulation of Economics Activity. The Brookings Institution, 1775 Massachusest Avenue, . N.W. Woshington D.C.

A.F. Elly Erawaty, 1999. Himpunan Makalah, Rangkuman Diskusi dan Kesimpulan Seminar : Membenahi Perilaku Pelaku Bisnis Melalui Undangundang Nomor 5 Tahun 1999 Tentang Larangan Praktek Monopoli dan Persaingan Usaha Tidak Sehat

Indra Setiawan and Yosi Pahala, Deregulasi Penerbangan dan Kinerja Perusahaan Penerbangan Niaga Berjadwal di Indonesia. Volume 02 Nomor 01, Maret 2015. ISSN-2355-4721 Jurnal managemen Transportasi \& Logistik.

Magretta, Joan, 2012, Understanding Michael Porter, The Essential Guide to Competition and Strategi, published by Harvard Business School, Copyright@2012.

Tiarto and Saptono, Berbagai Halangan Masuk Pada Bisnis Penerbangan Berjadwal di Indonesia, Volume 9 Nomor 18 Oktober 2014, Jurnal Ilmiah Aviasi "Langit Biru”. Sekolah Tinggi Penerbangan Indonesia.

Undang-undang Penerbangan Nomor 1 Tahun 2009.

Undang-undang Nomor 5 Tahun 1999 tentang Larangan Praktek Monopoli dan Persaingan Usaha Tidak Sehat.

Keputusan Menteri Perhubungan Nomor KM. 11 Tahun 2001 tentang Penyelenggaraan Angkutan Udara. 